\title{
The Case of Formula E
}

\begin{abstract}
Calls for research and practices with regard to sport management innovation are plenty. In this chapter we introduce why the electric racing world championship Formula $\mathrm{E}$ can be a relevant case study for a model of sport management innovation. Besides introducing our fivefold perspective on innovation (organizational, technological, commercial, social and community-based), the basics of Formula E and our approach to theoretical modelling, the chapter explains how the rest of the book is structured.
\end{abstract}

Keywords Sustainability $\bullet$ Case study $\bullet$ Automotive industry $\bullet$ Sport sociology

\section{INTRODUCTION}

Research on the links between sport and innovation is dominated by entrepreneurship, business, marketing and management perspectives (Kosmynin \& Ljunggren, 2021; Ratten, 2021). This is perhaps not very surprising, given that innovation as a scholarly field is considered by many to originate from the work of economist Joseph Schumpeter (1883-1950) (Fagerberg, 2005). Schumpeter defined innovation as a new commodity: a better quality product that involved new methods of production, new markets, new materials and new ways of organizing production (Schumpeter, 1983). Hence, for Schumpeter, innovation was closely tied to business, markets and competitive advantage that would bring financial

(C) The Author(s) 2021

H. E. Næss, A. Tjønndal, Innovation, Sustainability and

Management in Motorsports, https://doi.org/10.1007/978-3-030-74221-8_1 
gain. In other words, according to Schumpeter's understanding of innovation, it is crucial that any new idea, process or product should be commercialized and introduced to a market. The term 'innovation' has been further developed and transformed since Schumpeter's early conceptualizations. Now, it is an analytical concept that is linked to a wide range of different academic fields, including sociology, political science, organization and leadership studies, welfare and public sector services.

This diversification of theoretical perspectives on innovation has also reached the academic world of sport science. As suggested by Tjønndal's (2017) early literature review, there are at least five identifiable forms of sport innovation: (1) social, (2) technological, (3) commercial, (4) community-based and (5) organizational. We will return to each of these forms in the upcoming chapters in this book. What makes sport a particularly interesting research area for innovation is that sport organizations need to be continuously renewed in order to keep up with societal changes and at the same time respect tradition. For instance, the International Olympic Committee's (IOC) work to make the Olympic Games more youth oriented by including new Olympic disciplines such as sport climbing in Tokyo 2021, or the trial run for eSports in Paris 2024, are two examples of how sport organizations adapt to changes in society. In this case, changing trends in what types of sports that are popular among youth. However, in sport organizations, 'glory days' and commercial innovations are in many respects each other's adversaries, and here motorsport is no exception (Nrss, 2014). In other words, just as with public sector and corporate businesses, in sport organizations there are both barriers and drivers for innovation.

From an innovation perspective, however, tradition and commercialization can in some cases be considered as allies. This perspective has been explored in the context of the World Rally Championship (Næss, 2014, 2017; Nass \& Tickell, 2019), but recently another motorsport championship has entered centre stage which may serve as an ever better example of this claim: Formula E (FE) — an all-electric single-seater racing series (Fig. 1.1) resembling Formula 1 in appearance, flair and technological advancement, but with a clear sustainability message. 


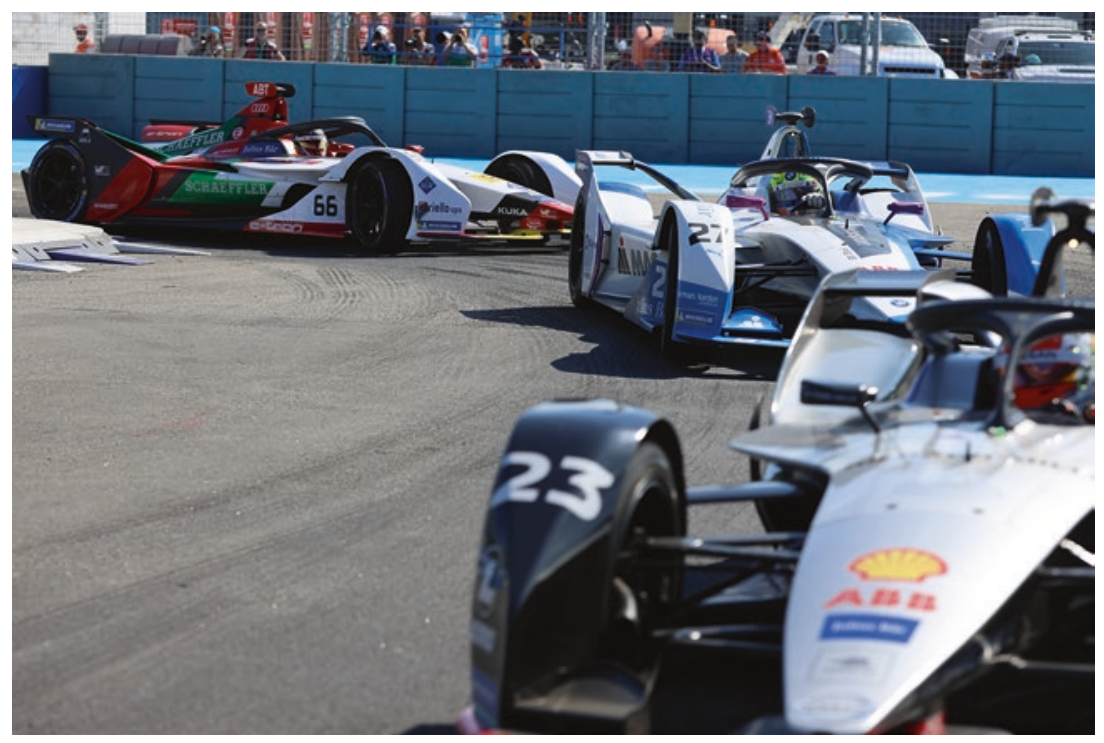

Fig. 1.1 Sébastien Buemi (23), Alexander Sims (27) and Lucas Di Grassi (66) during the 2019 ABB FIA Formula E Championship in New York City. (Photo: Andrew Henkelmann/Wikipedia, reprinted using Creative Commons license CC BY-SA 4.0)

Hailed in 2018 and 2019 by Medium and TIME Magazine as driving electric mobility innovation, ${ }^{1}$ corporations like ABB and government officials in both old and emerging states have been flocking to the championship since it started in 2014. The business magazine Management Today cheered for the championship that showed it was money in sustainable innovation $^{2}$ at a time when Formula 1 was accused of 'greenwashing' (Miller, 2016). Recently, sponsors have thrown caution to the wind, moved from Fl to Formula $\mathrm{E}$ and lined up as the 'greenfluencing' opportunities have become solid (Næss, 2020). In academia, Skinner et al. (2018), who under the heading The Future Impact of Culture on Innovation in Sport Enterprises emphasized that Formula E

is perhaps part of not only the future of sport but also the world. An electric car series represents the defining spirit or mood of this period of history, as shown by the ideas and beliefs of this period, while giving an industry synonymous with environmental waste a chance to attract a different audience. (Skinner et al., 2018, p. 265) 
In its current state, Formula E has two aces up its sleeve. Having exclusive rights from Fédération Internationale de l'Automobile (FIA) to stage an electric world championship until 2039-with no electric Formula 1 for a while - and the credential achieved in 2019 of being the only racing championship in the world to receive ISO20121 certification (one of the world's strictest certifications of sustainable events). With an increasingly global reach (see Table 1.1), Formula E thus has a competitive advantage over other motorsports that makes further exploration of this phenomenon relevant.

However, like many other radical innovations in sport, the introduction of Formula $\mathrm{E}$ has been met with a mixture of enthusiasm and resistance. To understand what the Formula $\mathrm{E}$ has done right (and wrong) in terms of exploiting the alliance between tradition and innovation, we argue that one key lies in management innovation (Birkinshaw et al., 2008; Birkinshaw

Table 1.1 Season and races Formula 2014/2015-2019/2020

\begin{tabular}{|c|c|c|c|c|c|c|}
\hline Season & 1 & 2 & 3 & 4 & 5 & 6 \\
\hline Years & 2014-2015 & $2015-2016$ & 2016-2017 & $2017-2018$ & $2018-2019$ & 2019-2020 \\
\hline Race 1 & Beijing & Beijing & $\begin{array}{l}\text { Hong } \\
\text { Kong }\end{array}$ & $\begin{array}{l}\text { Hong } \\
\text { Kong }\end{array}$ & Ad Diriyah & Ad Diriyah \\
\hline Race 2 & Putrajaya & Putrajaya & Marrakesh & $\begin{array}{l}\text { Hong } \\
\text { Kong }\end{array}$ & Marrakesh & Ad Diriyah \\
\hline Race 3 & $\begin{array}{l}\text { Punta del } \\
\text { Este }\end{array}$ & $\begin{array}{l}\text { Punta del } \\
\text { Este }\end{array}$ & $\begin{array}{l}\text { Buenos } \\
\text { Aires }\end{array}$ & Marrakesh & Santiago & Santiago \\
\hline Race 4 & $\begin{array}{l}\text { Buenos } \\
\text { Aires }\end{array}$ & $\begin{array}{l}\text { Buenos } \\
\text { Aires }\end{array}$ & $\begin{array}{l}\text { Mexico } \\
\text { City }\end{array}$ & Santiago & $\begin{array}{l}\text { Mexico } \\
\text { City }\end{array}$ & $\begin{array}{l}\text { Mexico } \\
\text { City }\end{array}$ \\
\hline Race 5 & Miami & $\begin{array}{l}\text { Mexico } \\
\text { City }\end{array}$ & $\begin{array}{l}\text { Monte } \\
\text { Carlo }\end{array}$ & $\begin{array}{l}\text { Mexico } \\
\text { City }\end{array}$ & $\begin{array}{l}\text { Hong } \\
\text { Kong }\end{array}$ & Marrakesh \\
\hline Race 6 & Long beach & Long beach & Berlin & Rome & Rome & Sanya $a^{\mathrm{a}}$ \\
\hline Race 7 & $\begin{array}{l}\text { Monte } \\
\text { Carlo }\end{array}$ & Paris & Berlin & Paris & Paris & Rome \\
\hline Race 8 & Berlin & Berlin & Berlin & Paris & Paris & Paris $^{\mathrm{a}}$ \\
\hline Race 9 & Moscow & London & New York & Berlin & $\begin{array}{l}\text { Monte } \\
\text { Carlo }\end{array}$ & Jakarta ${ }^{\mathrm{a}}$ \\
\hline Race 10 & London & London & New York & Zürich & Berlin & New York \\
\hline Race 11 & London & & Montreal & New York & Bern & London $^{\mathrm{a}}$ \\
\hline Race 12 & & & Montreal & New York & New York & Berlin \\
\hline Race 13 & & & & & New York & Berlin \\
\hline Race 14 & & & & & & Berlin \\
\hline
\end{tabular}

${ }^{a}$ Cancelled due to the COVID-19 pandemic. The replacement races in Berlin were run in August 2020 
\& Mol, 2006; Damanpour, 2014). In contrast to much research on sport and innovation, it is here defined as ' a marked departure from traditional management principles, processes, and practices or a departure from customary organizational forms that significantly alters the way the work of management is performed' (Hamel, 2006, p. 3). If successful, Hamel argues, a management innovation creates a long-lasting advantage when it fulfils one or more of three conditions. First, is the innovation based on a novel principle that challenges management orthodoxy? Second, is it systemic, encompassing a range of processes and methods? Third, is it part of an ongoing invention programme, where progress compounds over time? Behind these changes lies a foundational principle: committing to a bigger problem (Hamel, 2006). Whether these criteria are fulfilled can be analysed through an examination of the key stages of management innovation:

The key central phase, invention, is preceded by a combination of dissatisfaction with the status quo (inside the company) and inspiration from others (typically outside the company). Invention is then followed by a process of validation both inside and outside the company. (Birkinshaw \& Mol, 2006, p. 85)

Consequently, in the forthcoming chapters we will explore how the story of Formula E from start-up to major business exemplifies the significance of management innovation as a way to facilitate five other forms of innovation in sport: organizational, technological, commercial, social and community-based. Based on data from a variety of multiple secondary sources (sustainability reports from Formula and its stakeholders, media data in English and French, podcasts and newspaper articles, partner publications, social media outputs etc.), we present a model of sport management innovation that aims to describe the relevant conditions for managerially enhancing a sports organization's commercial product.

\section{The Entry of Formula E into the World of Motorsports}

The idea of an all-electric racing championship is not alien to car manufacturers. In 1899 Belgian driver and engineer Camille Jenatzy drove flat out in his torpedo-shaped 'La Jamais Contente' ('never satisfied') in a sparsely populated area to the northwest of Paris and became the first person to reach more than $100 \mathrm{~km} / \mathrm{h}$ in a car. As a publicity stunt it created a place 
for Jenatzy in the growing demand for automobile transportation, even though the electric technology that put him in the books in the first place failed to dominate the car industry in the twentieth century. Three years later, the record was broken by a steam car and shortly after that was arguably demolished by an internal combustion engine-powered car recording $120.83 \mathrm{~km} / \mathrm{h}$. Despite Jenatzy earning the nickname of 'the Red Devil', due to his racing driver style being 'characterized by demoniacal fury and stark determination', ${ }^{3}$ his efforts to electrify motorsports would soon turn out to be in vain.

The reasons for the disappearance of the electric car were political, technological and cultural. Henry Ford and Thomas Edison teamed up for an electric car project in 1913-1914, but due to technological shortcomings and business disagreements Ford abandoned the project, and Edison's electricity campaign lost a major ally. ${ }^{4}$ Thanks to successful lobbying from oil companies to transform societies by means of petrol-driven cars (Dennis \& Urry, 2009) and an infrastructure that was adapted to the use of cars for leisure purposes (Schipper, 2008), the development and expansion of motorsport followed. The European car industry cashed in on the development by establishing Association Internationale des Automobile Clubs Reconnus (AIACR) in 1904, which from 1945 became the Fédération Internationale de l'Automobile (FIA) and established itself as the global governing body of motorsport and automobility. When Formula 1 launched its first world championship in 1950, and FIA's World Rally Championship (WRC) followed in 1973, car manufacturers and engineers relied on petrol-powered ingenuity for wins and brand exposure. Formula 1 has now become the epitome of racing and a commercial giant (Stuart, 2018; Sturm, 2014). In 2019, the participating teams spent a total of US\$2.6 billion on their efforts to win the championship (Sylt, 2018).

In the meantime, Formula $\mathrm{E}$ appeared in the world of motorsport with its first-ever race in Beijing, China, in 2014. Founded in 2011 by the Spanish duo Enrique Banuelos and Alejandro Agag, a billionaire businessman and former Member of the European Parliament and motorsport entrepreneur, respectively, this was an all-electric championship that in 12-14 venues around the world showcased a combination of sustainability claims, entrepreneurial spirit and commercial savviness that were unique to racing. All the teams used cars that were aerodynamically similar but had minor technological differences, and were transported around the world by Formula E's logistical partner DHL. The timing of Formula E as 
a new sustainable motorsport proved to be perfect, especially as the car world was reeling from the Volkswagen (VW) emissions scandal (also known as 'Dieselgate' or 'Emissionsgate') in 2015. Then it became known that VW had intentionally programmed turbocharged direct injection (TDI) diesel engines to only activate their emission controls during laboratory emissions testing. This caused the vehicles' nitrogen oxides $\left(\mathrm{NO}_{\mathrm{X}}\right)$ output to meet air pollution standards during regulatory testing, but emit up to 40 times more $\mathrm{NO}_{\mathrm{X}}$ in real-world driving.

After its success in its opening race in Beijing in 2014, Formula E (FE) went on to publish the book The eStory: Undertaking the Mobility Challenge in 2015. A confessional tale penned by DHL's sustainability director (FE's logistics partner) and business school lecturer Manoella Wilbaut, it specifies the values and mission of Formula E. The book's subtitle is Sustainable Development fueled by Innovation, with the content divided into three sections (Wilbaut, 2015). The first section is about thinking differently about consumer adaptations and caters to the values of Generation Y, rather than emulating the grandstand culture of Formula 1 or the working class atmosphere of the WRC (Bradley, 2017; Næss, 2014; Næss \& Tickell, 2019). The second part concerns technological progress and explains electric mobility solutions that can ramify the automotive industry and urban transportation in depth. The third section covers innovation for sustainable development, where Wilbaut draws on Joseph Schumpeter's (1983) view of innovation as 'making ideas work technically and commercially' (2015, p. 77), as well as on established theoretical innovation categorizations such as 'radical' and 'incremental' innovations (Fagerberg, 2005). As we will demonstrate in the upcoming chapters, all three forms of innovation can be said to characterize the championship's development.

Despite these achievements, Formula E has struggled to convince people of its brand proposition. On the one hand, there is the devil within. Over the years car manufacturers have accumulated vast amounts of knowhow on electric cars. The championship may therefore become a hindrance in terms of innovative solutions, unless the rulebook keeps track of what is in it for BMW, Jaguar and Porsche, to name but a few. For example, the latter's Taycan model, its first full-electric car, has a peak charging capacity of $270 \mathrm{~kW}$, one the fastest electric vehicles (EVs) currently sold. However, all 2020 Formula E cars charge at a peak rate of $100 \mathrm{~kW}$. Die-hard motorsport fans, moreover, have mocked the racetracks, which were purposebuilt in city areas, and the cars, which were nicknamed 'hairdryers' due to the lack of classic racing sounds. Others have ridiculed the fact that drivers 
in the early seasons had to change cars during the race because the batteries did not last very long and moaned about the lack of performance. Especially heated was the debate about 'Fanboost' (an e-voting service providing your favourite driver with extra power in the race; see Chap. 5).

On the other hand, some critics dismiss Formula $\mathrm{E}$ as the all-singing, all-dancing solution. In Les sports mécaniques, une arme de destruction massive, French author Paul Ariès (2018) claims that motorsport is a 'weapon of mass destruction' that causes thousands of deaths through accidents and pollution, and that Formula $\mathrm{E}$ is not changing that one bit. Criticizing how motorsport is aided by powerful political allies such as the former French prime minister, François Fillon, who is currently FIA's Manufacturer Commission President, Ariès lashes out to French politicians who see Formula $\mathrm{E}$ as a saviour, nicknaming it 'chère à la Maire de Paris' ('the Mayor of Paris's pet'), and concludes that electric cars are simply the last great myth before the ecological disaster hits us all. While Ariès' book is somewhat hyperbolic, the critique towards Formula E for being hypocritical in its sustainability vision-as the electric teams consist of manufacturers with more than 90 per cent of fossil-fuelled vehicles-is unlikely to go away. Despite Formula E achieving net zero carbon status in 2020, as only one of three companies in the world apart from Google and Microsoft, there is something paradoxical, and almost comical, about electric cars being branded as sustainable motorsport when they are shipped and air transported around the world for sporting events.

\section{The Positioning of This Study}

Whatever one may think of Formula E's credibility in terms of sustainability challenges there is nevertheless something fascinating about its path from Agag's description of it as an 'idea on a napkin' (cited from Kingham, 2016) in 2011, to being granted world champion status by FIA in 2020 and a global popular culture phenomenon. In 2014 Agag said: 'We began as a start-up with lots of ideas and a bit of money because it was always a project with a large dimension and large vision. We did everything that we needed to do in order to attract large sponsors. ${ }^{5}$ Seven years later, the company list shareholders such as the Swiss private banking group Julius Baer, Discovery Communications and NewWave (the parent of Weibo, China's answer to Twitter), as well as corporate media giant Liberty Global, which has a 23.9 per cent stake and is also the major shareholder in Formula 1. Although it could be claimed that financial boosts along the 
way from new investors have saved Formula E, its success is also due to its organizational adaptivity and partnership strategy.

Of late, the number of research outputs investigating Formula $\mathrm{E}$ has therefore rapidly increased. These roughly divide into media explorations (Robeers, 2019; Robeers \& Van den Bulck, 2018), human-digital interactions (Finn, 2020; Jarvenpaa \& Standaert, 2017), event studies (Sturm, 2019) and studies of Formula E's commercial ramifications (Nrss, 2020). However, its innovation history is unexplored territory. Through our exploration, we will demonstrate that sport organizations should not 'treat an innovation as if it were a well-defined, homogenous thing that could be identified as entering the economy at a precise date-or becoming available at a precise point in time' (Kline \& Rosenberg, 1986, p. 283). Rather, following Kline and Rosenberg (1986) one step further, the examination focuses on the complex iterative feedback loops between various parts of the organization and its stakeholders. More specifically, Formula E has employed an innovation strategy of drilling holes in a funnel in order to allow ideas to permeate from different places. This metaphor demonstrates the necessity of collaboration and that ideas developed in an open innovation ecosystem 'fuel internal developments and serve as an inspiration for a broader external environment' (Wilbaut, 2015, p. 79). Formula E's approach to innovation has led us to focus on all parts of the championship, instead of just the competition.

Second, further research on management in this sense could be useful to motorsports organizations, fans, leaders and practitioners. Although attention has been given to the life and career of Formula 1 entrepreneur Bernie Ecclestone (Stuart, 2018), as well as the occasional entry into strategy and business (Brawn \& Parr, 2016), most research has concentrated on Formula 1 in general. Despite a plethora of innovative features and the work of 'Fl professor' Mark Jenkins (see Jenkins et al., 2016), ${ }^{6}$ the focus has been more on the dramaturgy of the championship than sport innovation in a societal or managerial context. Hence, this work represents an inward focus on Formula 1, rather than an outward focus on large societal issues relating to the sustainability of motorsport. In spite of recurrent warnings about the ecological footprint of motorsport being too big (Dingle, 2009; Hassan \& O'Kane, 2011; Mackellar, 2013; Miller, 2016), studies of innovation in motorsport have focused on technological progress related to vehicle performance (Ebaid et al., 2016; Foxall \& Johnston, 1991; Jenkins \& Floyd, 2001). Even though the technology and performance of racing cars have advanced, the major motoring 
championships - even high-tech ones like Formula 1-have hardly changed. In 2007, there was a disagreement between notable motorsport figures about the future of management. On the one hand, Pat Symonds, a former racing engineer and now Formula l's chief technical officer as well as visiting professor at Cranfield University in the UK, claimed that 'Surprisingly, for such a dynamic sport, there's a remarkable amount of conservatism in management. Globalization presents a huge challenge to those who are conservative' (Henry et al., 2007, p. 147). On the other hand, Jackie Stewart, former Formula 1 world champion and Fl team owner, scoffed at the 'managerialism' that he claimed was diluting the essence of the motorsport drive:

the problem is that you bring in such so called expertise, the further you are from employing and using the passion that is absolutely vital to this business. In my experience, such development has a generally negative effect. (Henry et al., 2007, p. 147)

Instead, Stewart sees 'passion'- the most important ingredient in motorsport-as 'simply not synonymous with corporate management structures' (Henry et al., 2007, p. 147). Based on what is discussed in this book, what we have learned from practical experience of sport management in racing and research on sport innovation and entrepreneurship, it seems likely that in the light of Formula E's development Symonds was closer to the answer than Stewart. The need for innovation outside the pits is equally important as that on the racetrack, and would seem to require an iterative process in which numerous stakeholders are involved in the ecosystem of innovation that a business like Formula E represents.

Third, previous research points to the potential of exploring Formula $\mathrm{E}$ in a theoretical context. In terms of selecting Formula $\mathrm{E}$ as a case of the importance of management innovation in sport, we argue that it resembles the logic posed by Eisenhardt and Graebner (2007), who claim that 'theoretical sampling simply means that cases are selected because they are particularly suitable for illuminating and extending relationships and logic among constructs' (p. 27). But whereas Eisenhardt and Graebner (2007) favour multiple cases 'because the propositions are more deeply grounded in varied empirical evidence' $(2007$, p. 27$)$, our study draws on the extended case method outlined by Burawoy (1991). This design is singlecase based and can be coupled with other types of explorations than participant observation, which is usually favoured by Burawoy (Ridder, 2017, 
p. 292) because it 'is guided by anomalies that ... demonstrates that the theory is incomplete' (Ridder, 2017, pp. 291-292). In other words, as Formula $\mathrm{E}$ contrasts most of what is done in motorsports generally, 'theory is aimed to be improved by "turning anomalies into exemplars" (Burawoy, 1991, p. 10). This turn requires acknowledging a broad spectrum of perspectives on the given situation and, second, interpreting the micro-macro links in social processes by aggregating those perspectives.

\section{A Guide to the Rest of the Book}

By making use of the sport innovation typology created by Tjønndal (2017) as described above, the discussion in the upcoming chapters is meant to create conceptual associations between conditions for management innovation in sport rather than being tested empirically (Gilson \& Goldberg, 2015). In addition to enabling us to carve out propositions that will be used as building blocks in our model, the organization of the chapters has three functions: (1) to develop a cumulative argument of why Formula E provides case-based learning potential for other sporting organizations, (2) to provide the leap from start-up to multibillion industry with a categorical narrative and (3) to respond to a criticism of studies of organizational changes in sport, where although what happened is usually accounted for, the processes of how it happened are 'rarely addressed in detail' (Caza, 2000, p. 230).

Based on our analysis, the sport management innovation model takes form as an ecosystem. While 'ecosystem' is not a new metaphor for describing the circulation of ideas and practices in sport management innovation in working life or in academia (Kapoor, 2018), it is insufficiently theorized as a framework of analysis. To rectify this shortcoming, we make use of the following definition: 'a loosely interconnected network of companies and other entities that coevolve capabilities around a shared set of technologies, knowledge, or skills, and work cooperatively and competitively to develop new products and services' (Nambisan \& Baron, 2013, p. 1076). This definition is the point of departure for our exploration of the five types of innovation associated with Formula E. Second, we analyse the innovation history of Formula $\mathrm{E}$ as a form of 'managed ecosystem' which can explored in 'situations where a central orchestrating organization manages ecosystem interactions such that the locus of activity is outside organizational boundaries, while the locus of control remains within the organization' (Altman et al., 2019, p. 3). 
We hasten to underline that much of the empirical data and history of Formula E presented along the way is not new. Rather, our primary contribution is to synthesize opinions, facts and insights in order to strengthen our model for sport management innovation. The conclusion offers a number of suggestions for motorsport entrepreneurs in particular and sport entrepreneurs in general who want to replicate Formula E's success, yet avoid getting trapped in its weaknesses.

\section{Notes}

1. 'Formula E drives electric mobility innovation, Medium.com, 26 February 2018. Retrieved 20 April 2020 from https://medium.com/world-ofopportunity/formula-e-drives-electric-mobility-innovation-9ca784a49bb0; 'Why This Electric Car Racing League Matters Even If You Don't Care About Cars', Time Magazine, 10 July 2019. Retrieved 20 April 2020 from https://time.com/5622578/formula-e/

2. 'Formula E shows there's money in sustainable innovation', Management Today (n.d.). Retrieved 20 April 2020 from https://www.managementtoday.co.uk/formula-e-shows-theres-money-sustainable-innovation/futurebusiness/article/1592186

3. 'The Phallic French EV That Was Once the World's Fastest Car', Wired.com, 9 October 2014. Retrieved 20 April 2020 from https://www.wired. com $/ 2014 / 10 /$ phallic-french-ev-worlds-fastest-car/

4. 'Ford, Edison and the Cheap EV That Almost Was', Wired.com, 18 June 2010. Retrieved 16 April from https://www.wired.com/2010/06/ henry-ford-thomas-edison-ev/

5. 'Alejandro Agag: In the corridors of power-Part 2', motorsport.com, 4 October 2015. Retrieved from https://www.motorsport.com/formula-e/ news/alejandro-agag-in-the-corridors-of-power-part-2/647039/

6. For more, see http://www.fl professor.com/

\section{REFERENCES}

Altman, E. J., Nagle, F., \& Tushman, M. L. (2019). Managed ecosystems and translucent institutional logics: Engaging communities. Working paper 19-086, Harvard Business School.

Ariès, P. (2018). Les sports mécaniques, une arme de destruction massive.

Birkinshaw, J., Hamel, G., \& Mol, M. J. (2008). Management innovation. Academy of Management Review, 33(4), 825-845.

Birkinshaw, J., \& Mol, M. J. (2006). How management innovation happens. MIT Sloan Management Review, 47(4), 81-88. 
Bradley, C. (Ed.). (2017). Formula 1 in 2017. Global fan insight into the world's largest annual sporting series (2005-2017). FIA/Motorsport Network.

Brawn, R., \& Parr, A. (2016). Total competition. Lessons in strategy from Formula One.

Burawoy, M. (1991). Ethnography unbound. Power and resistance in the modern metropolis.

Caza, A. (2000). Context receptivity: Innovation in an amateur sport organization. Journal of Sport Management, 14(3), 227-242.

Damanpour, F. (2014). Footnotes to research on management innovation. Organization Studies, 35(9), 1265-1285. https://doi.org/10.1177/01708 40614539312

Dennis, K., \& Urry, J. (2009). After the Car. Polity.

Dingle, G. (2009). Sustaining the race: A review of literature pertaining to the environmental sustainability of motorsport. International Journal of Sports Marketing and Sponsorship, 11(1), 75-91.

Ebaid, M. S., Ammoura, S., \& Al-khishali, K. J. (2016). Design, build, and test a formula student racing car: An educational engineering exercise at Philadelphia University. International Journal of Mechanical Engineering Education, 44(1), 56-93. https://doi.org/10.1177/0306419015624984

Eisenhardt, K. M., \& Graebner, M. E. (2007). Theory building from cases: Opportunities and challenges. Academy of Management Journal, 50, 25-32.

Fagerberg, J. (2005). Innovation: A guide to the literature. In J. Fagerberg, D. C. Mowery, \& R. R. Nelson (Eds.), The Oxford handbook of innovation.

Finn, M. (2020). From accelerated advertising to Fanboost: Mediatized motorsport. Sport in Society. https://doi.org/10.1080/17430437.2019.1710131

Foxall, G. R., \& Johnston, B. R. (1991). Innovation in Grand Prix Motor Racing: The evolution of technology, organization and strategy. Technovation, 11(7), 387-402.

Gilson, L. L., \& Goldberg, C. B. (2015). Editors' comment: So, what is a conceptual paper? Group \& Organization Management, 40(2), 127-130.

Hamel, G. (2006). The why, what, and how of management innovation. Harvard Business Review. February issue, 1-17. https://hbr.org/amp/2006/02/ the-why-what-and-how-of-management-innovation

Hassan, D., \& O'Kane, P. (2011). The great race across the Sahara: A history of the Paris to Dakar Rally and its impact on the development of corporate social responsibility within motor sport. The International Journal of the History of Sport, 28(2), 268-280. https://doi.org/10.1080/09523367.2011.537917

Henry, N., Angus, T., Jenkins, M., \& Aylett, C. (2007). Motorsport going global. The challenges facing the world's motorsport industry. Palgrave Macmillan.

Jarvenpaa, S. L., \& Standaert, W. (2017). Emergent ecosystem for radical innovation: Entrepreneurial probing at Formula E. Proceedings of the 50th Hawaii International Conference on System Sciences, 4736-4745. Retrieved April 
16, 2020, from https://aisel.aisnet.org/cgi/viewcontent.cgiłarticle=1593 \&context $=$ hicss -50

Jenkins, M., \& Floyd, S. (2001). Trajectories in the evolution of technology: A multi-level study of competition in Formula 1 racing. Organization Studies, 22(6), 945-969. https://doi.org/10.1177/0170840601226003

Jenkins, M., Pasternak, K., \& West, R. (2016). Performance at the limit: Business lessons from Formula $1 \circledR$ motor racing (3rd ed.). Cambridge University Press.

Kapoor, R. (2018). Ecosystems: Broadening the locus of value creation. Journal of Organizational Design, 7(12), 1-16.

Kingham, B. (2016, March 40-59). On the subject of power. Current E. Retrieved March 17, 2017, from https://current-e.com/features/on-the-subject-ofpower/

Kline, S. J., \& Rosenberg, N. (1986). An overview of innovation. In R. Landau \& $\mathrm{N}$. Rosenberg (Eds.), The positive sum strategy: Harnessing technology for economic growth (pp. 275-304). National Academy Press.

Kosmynin, M., \& Ljunggren, E. C. (2021). Social innovation and social entrepreneurship-Useful theories for sport? In A. Tjønndal (Ed.), Social innovation in sport (pp. 19-35). Palgrave Macmillan.

Mackellar, J. (2013). World Rally Championship 2009: Assessing the community impacts on a rural town in Australia. Sport in Society, 16(9), 1149-1163. https://doi.org/10.1080/17430437.2013.790893

Miller, T. (2016). Greenwashed sports and environmental activism: Formula $\mathrm{l}$ and FIFA. Environmental Communication, 10(6), 719-733. https://doi.org/1 $0.1080 / 17524032.2015 .1127850$

Nxss, H. E. (2014). A sociology of the World Rally Championship. Palgrave Macmillan.

Næss, H. E. (2017). Authenticity matters. A digital ethnography of FIA World Rally Championship fan forums. Sport Management Review, 20(1), 105-113.

Næss, H. E. (2020). Corporate greenfluencing: A case study of sponsorship activation in Formula E motorsports. International Journal of Sports Sponsorship and Marketing. https://doi.org/10.1108/IJSMS-09-2019-0106

Næss, H. E., \& Tickell, S. (2019). Fan engagement in motorsports. The case of the 'RallytheWorld' campaign. Journal of Media Innovations. https://doi. org/10.5617/jomi.6289.

Nambisan, S., \& Baron, R. A. (2013). Entrepreneurship in innovation ecosystems: Entrepreneurs' self-regulatory processes and their implications for new venture success. Entrepreneurship Theory and Practice, 37(5), 1071-1097.

Ratten, V. (2021). Innovation and entrepreneurship in sport management. Edward Elgar Publishing.

Ridder, H. (2017). The theory contribution of case study research designs. Business Research, 10, 281-305. https://doi.org/10.1007/s40685-017-0045-z 
Robeers, T. (2019). 'We Go Green in Beijing': Situating live television, urban motor sport and environmental sustainability by means of a framing analysis of TV broadcasts of Formula E. Sport in Society. https://doi.org/10.108 0/17430437.2018.1558212

Robeers, T., \& van den Bulck, H. (2018). Towards an understanding of sidelining environmental sustainability in Formula E: Traditional values and the emergence of eSports. Athens Journal of Sports, 5(4), 331-350.

Schipper, F. (2008). Driving Europe. Building Europe on roads in the twentieth century. Technische Universiteit Eindhoven.

Schumpeter, J. A. (1983). The theory of economic development: An inquiry into profits, capital, credit, interest, and the business cycle. Transaction Books.

Skinner, J., Smith, A. C. T., \& Swanson, S. (2018). Fostering innovative cultures in sport. Leadership, innovation and change. Palgrave Macmillan.

Stuart, S. A. (2018). Bernie Ecclestone: Formula One's entrepreneurial ringmaster. In E. Bayle \& P. Clastres (Eds.), Global sport leaders: A biographical analysis of international sport management (pp. 363-394). Palgrave Macmillan.

Sturm, D. (2014). A glamorous and high-tech global spectacle of speed. Formula One motor racing as mediated, global and corporate spectacle. In K. Dashper, T. Fletcher, \& N. McCullough (Eds.), Sports events, society and culture (pp. 86-100). Routledge.

Sturm, D. (2019). Formula E's green challenge to motorsport events, spaces and technologies. In H. Seraphin \& E. Nolan (Eds.), Green Events and Green Tourism: An international guide to good practice (pp. 165-173). Routledge.

Sylt, C. (2018, April 8). Revealed: The \$2.6 billion budget that fuels Fl's 10 teams. Forbes. Retrieved April 12, 2020, from https://www.forbes.com/sites/ csylt $/ 2018 / 04 / 08 /$ revealed-the-2-6-billion-budget-that-fuelsfls-ten-teams/\#11645d9f6595

Tjønndal, A. (2017). Sport innovation: Developing a typology. European Journal for Sport and Society, 14(4), 291-310. https://doi.org/10.1080/1613817 1.2017 .1421504

Wilbaut, M. (2015). The eStory: Undertaking the mobility challenge. FIA Formula E. Retrieved September 9, 2018, from http://admin.fiaformulae.com/ media/301817/estory_undertaking-the-challenges-of-sustainablemobility.pdf 
Open Access This chapter is licensed under the terms of the Creative Commons Attribution 4.0 International License (http://creativecommons.org/licenses/ by $/ 4.0 /)$, which permits use, sharing, adaptation, distribution and reproduction in any medium or format, as long as you give appropriate credit to the original author(s) and the source, provide a link to the Creative Commons licence and indicate if changes were made.

The images or other third party material in this chapter are included in the chapter's Creative Commons licence, unless indicated otherwise in a credit line to the material. If material is not included in the chapter's Creative Commons licence and your intended use is not permitted by statutory regulation or exceeds the permitted use, you will need to obtain permission directly from the copyright holder. 